\title{
Effect of Moringa oleifera Leaves Extract Against Hematology and Blood Biochemical Value of Patients with Iron Deficiency Anemia
}

\author{
Dona Suzana', Franciscus D. Suyatna ${ }^{2}$, Azizahwati ${ }^{3}$, Retnosari Andrajati ${ }^{3}$, Santi Purna Sari' ${ }^{3}$, Abdul Mun'im ${ }^{4}$ \\ 'Graduate Program of Herbal Medicine, Faculty of Pharmacy, Universitas Indonesia, Kampus Baru UI Depok, INDONESIA. \\ 2Department of Pharmacology, Faculty of Medicine, Universitas Indonesia, Jakarta, INDONESIA. \\ ${ }^{3}$ Department of Pharmacology, Faculty of Pharmacy, Universitas Indonesia, Kampus Baru UI Depok, INDONESIA. \\ ${ }^{4}$ Department of Pharmacognosy-Phytochemistry, Faculty of Pharmacy, Universitas Indonesia, Kampus Baru UI Depok, INDONESIA.
}

\begin{abstract}
Introduction: Approximately (24.8\%) the world's population suffers from anemia and $50 \%$ of an anemic case is due to iron deficiency. This study investigated the efficacy of Moringa oleifera $L$ leaves to extract as an iron booster and supplement to help overcome anemia in the community. Methods: It was a randomized, double-blind, placebo-controlled study in anemic women (hemoglobin $8-12 \mathrm{~g} / \mathrm{dL}$ ), in which the water extract of moringa leaves was examined as an add-on therapy in the subject treated with ferrous sulfate $1200 \mathrm{mg} /$ tablet). Thirty-five women subject of $16-49$ years old were divided into 17 of moringa leaves and 18 of control. The extract of moringa leaves of $1400 \mathrm{mg}$ was formulated in capsules and was administrated daily for 3 weeks. Results: The result showed there were significantly increase of mean of hemoglobin $(0.794 \pm 0.81 \mathrm{~g} / \mathrm{dL})$, ferritin $(29.378 \pm 42.48 \mathrm{ng} / \mathrm{mL}), \mathrm{MCHC}$ (Mean Corpuscular Haemoglobin Concentration) $(2.459 \pm 2.86 \mathrm{~g} / \mathrm{dL}), \mathrm{RDW}$ (Red Distribution Wide) $(1.4 \pm 2.07 \%)$ and decreased of platelets $(36529.41 \pm 59024.48 / \mathrm{uL})$. The control groups were significantly increased of mean of the hemoglobin $10.644 \pm$ $0.83 \mathrm{~g} / \mathrm{dL})$, erythrocytes $(0.475 \pm 0.523 \mathrm{Tpt} / \mathrm{L})$, hematocrit $(2.189 \pm 14.08 \%)$, MCV (Mean Corpuscular Volume)( $4.756 \pm 8.91 \mathrm{fL}), \mathrm{MCH}(2.183 \pm 2.47 \mathrm{pg})$ dan RDW
\end{abstract}

$(2.844 \pm 2.80 \%)$. The hematocrit $(3.14 \pm 1.47 \%), \mathrm{MCH}$ (Mean Corpuscular Hemoglobin) $(3.495 \pm 1.33 \mathrm{pg}), \mathrm{MCHC}(3.264 \pm 0.96 \mathrm{~g} / \mathrm{dL})$ values of moringa leaves were significantly higher whereas the platelets count $(55251.63 \pm 23404 / \mathrm{uL})$ of moringa leaves were significantly lower $(p<0.05)$ than those of control group. Conclusion: It can be concluded that moringa leaves extract could improve iron deficiency anemia in women.

Key words: Anemia, Ferrous sulfate, Ferritin, Hematology, Moringa oleifera.

Correspondence:

Abdul Mun'im

Department of Pharmacognosy-Phytochemistry, Faculty of Pharmacy,

Universitas Indonesia, Kampus Baru UI Depok, INDONESIA.

Phone no: 62-21-7270031

Email: munim@farmasi.ui.ac.id

DOI: 10.5530jyp.2017.1s.20

\section{INTRODUCTION}

Approximately 162 billion people (24.8\%) the world's population suffer from anemia ${ }^{1}$ and $50 \%$ of an anemic case is due to iron deficiency. ${ }^{2}$ According to data from Department of Health of the Republic of Indonesia (2013) prevalence of anemia is about $21.7 \%$, and the prevalence of iron deficiency anemia in women aged $15-50$ years in Indonesia is about $33.1 \%$ and young women is about $28 \%$.

Iron deficiency anemia can cause both growth disruption and disruption of physical and mental development, lower intellectual, ability to learn, ability to exercise, impaired cognitive development and behavior. A weakened immune system, susceptibility to infection would lower health status thereby reducing the capacity, productivity, and creativity of adolescents ${ }^{3}$, and during pregnancy can increase the complications, the risk of maternal mortality, the rate of prematurity, low birth weight and perinatal mortality rate. ${ }^{4,5}$

Moringa oleifera L (family: Moringaceae) is a kind of herbaceous plant used since ancient African communities to overcome malnutrition. It is known that moringa's fresh leaves contain vitamin $\mathrm{C}$ seven times more than oranges, vitamin A four times more than carrots, calcium four times more than milk, potassium three times more than bananas and protein two times more than yogurts. ${ }^{6}$ It is traditionally used for anemia, anxiety, asthma, blackheads, bronchitis, catarrh, cholera, conjunctivitis, cough, diarrhea, eye and ear infections, fever, swollen glands, headache, abnormal blood pressure, hysteria, pain in the joints, acne, and psoriasis. ${ }^{6}$ In the previous study, moringa leaves extract demonstrated anti-anemia activity in rats induced aniline. ${ }^{8}$

Chemical constituents of moringa leaves have been reported to have antihypertensive effects, anticancer, and antibacterial activity, namely 4 (4'-O-acetyl- $\alpha$-L-rhamnopyranosyloxy) benzyl isothiocyanate, 4-( $\alpha$-Lrhamnopyranosyloxy) benzyl isothiocyanate, niazimicin A and B pterygospermin, benzyl isothiocyanate, and 4-(a-L-rhamnopyranosyloxy) benzyl glucosinolate. ${ }^{6}$ Moringa has been reported to have antimicrobial activity / biocidal, an analgesic, anti-inflammatory, antidiabetic, antispasmodic, and antiulcer. ${ }^{8}$ Until now, there is no clinical studies using moringa leaves extract as an anti-anemia.

\section{METHODS}

Leaves extract of Moringa oleifera were prepared by maceration methods and continued with a dry vacuum system, maltodextrin filler addition on extracts which may increase the mass. Each capsule contains $700 \mathrm{mg}$ moringa leaves extract. The nutrient screening was conducted for the extract, including protein and vitamin $\mathrm{C}$.

\section{Iron and screening of phytochemical constituent.}

The iron content in the extract was analyzed using atomic absorption spectrophotometer according to the previous method. ${ }^{7}$ Phytochemical constituent such as alkaloid, flavonoid, terpene, saponin, glycoside and 
anthraquinone in the extracts was performed by according to the previous method.?

\section{Research Design}

Single-center, randomized, placebo-controlled trial, parallel design, enrolling anemic women 16-49 years olds. Patients were randomized into 2 groups within which they were received moringa leaves extract $1400 \mathrm{mg} /$ day with $200 \mathrm{mg}$ ferrous sulfate or placebo consist of ferrous sulfate 300 mg. Inclusion criteria was women that selected by anamnesis and initial screening with women's hemoglobin levels $(8-12 \mathrm{~g} / \mathrm{dL})$ and not taking NSAIDs, aspirin, and corticosteroids in the long term. Exclusion criteria were pregnant or breastfeeding women, suffer from malabsorption syndrome, history of sickle cell anemia or thalassemia, chronic bleeding, have an anti-anemia drugs before and during the study, and suffering from severe constipation and allergies to moringa leaf.

Research protocol has been reviewed and approved by The Ethics Committee of Faculty of Medicine, Universitas Indonesia (No. 625/H2.F1/ ETIK/2013). Patients 16 years or older (42 patients) from senior high school in Depok fulfilling the anamnesis and hematology examination. All patients were gave written informed consent for participation and randomized into 2 groups which had three weeks treatment, followed by hematology test. Seven patients had drop out criteria during research because of non-adherence and side effect of the extract.

\section{Data Analysis}

The tests conducted were Pair sample $t$-test or Wilcoxon signed rank test to determine differences in mean statistically significant from the two treatment groups of interconnected (before and after the test on each group). While the independent sample $t$-test or Mann-Whitney test was performed to determine the mean difference was statistically significant between the two treatment groups were not interconnected (the mean before and after group's moringa with the mean before and after control group).

\section{RESULTS AND DISCUSSION}

\section{Analysis of nutrient and phytochemical screening of moringa leaves extract}

The extract contained $27.33 \%$ protein using Kjeldahl method. Total iron content in Moringa extract of the averages $14.67 \mathrm{mg} / 100 \mathrm{~g}$ extract. The extract contained vitamin C was $759.05 \mathrm{mg} / 100 \mathrm{~g}$ with HPLC. Analysis levels of nutrients in the capsules used in the research was calculated based on the amount of iron substance in $100 \mathrm{~g}$ of extract. If one capsule with $700 \mathrm{mg}$ of the extract the contained iron levels are $0.103 \mathrm{mg}$ of iron/ capsules, vitamin C $5.313 \mathrm{mg} /$ capsule and protein levels of $39.043 \mathrm{mg}$ in one capsule. The result of phytochemical screening can be seen in Table 1.

Comparing the nutrient level of vegetables (spinach and cinnamon leaf) that are often used to overcome the problem of malnutrition and nutrition world. ${ }^{9}$ Spirulina is blue algae from marine natural products that contain the highest protein and iron. ${ }^{10}$ In 1 tablet $(500 \mathrm{mg})$ spirulina contains 0.9 to $3 \mathrm{mg}$ of iron and $300 \mathrm{mg}$ protein/ tablet. Compared to cinnamon leaf and spinach, moringa leaves have a protein content almost twice and four times higher than that cinnamon leaf and spinach, iron in moringa leaves is four times higher than spinach and five times higher than cinnamon leaf while the vitamin $\mathrm{C}$ of moringa leaves are 12 times higher than cinnamon leaf and 15 times higher than spinach.

Protein and iron levels were lower in research of Nweze, Onyekwere \& Felix (2014), which are proteins (18.92\%), and iron (3.66\%), and in research of Triandita (2013) levels of iron in the water extract of moringa

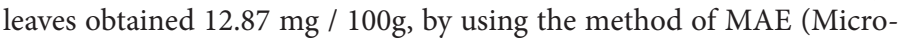

wave Assisted Extraction) Vitamin C test using titration method while iron content analysis using atomic absorption spectrometry method (AAS). In the extraction simplest process, we used a method of maceration, percolation, filtration, evaporation that terminated by using a vacuum drying system for drying the extract, maltodextrin filler addition on extracts which may increase the mass and reduce the levels of nutrients extracts.

Comparison nutrition levels of vegetables (spinach and katuk leaf (Sauropus androgynous)) that are often used to overcome the problem of malnutrition and nutrition world. ${ }^{9}$ Spirulina is blue algae from marine natural products that contain the highest protein and iron. ${ }^{10}$ In 1 tablet (500 mg) spirulina contains 0.9 to $3 \mathrm{mg}$ of iron and $300 \mathrm{mg}$ of protein/ tablet. When compared katuk leaf and, moringa leaves have a protein content almost twice and four times of the katuk leaf and spinach, iron in moringa leaves is four times higher than spinach and five times higher than katuk leaf while the vitamin $\mathrm{C}$ of moringa leaves are 12 times higher than katuk leaf and 15 times higher than spinach.

\section{Patient Demographics Profile}

Characteristics of the patient were assessed from age, occupation or education, weight, height, and body mass index (BMI). Educational characteristics of the subjects are $94.23 \%$ subjects are senior high school students (high school) and 5.77\% work as employees and housewives. By the total number of subjects classified as mild anemia was $71.43 \%(25$ people) and anemia was $28.57 \%$ (10 people).

Based on Table 2 anthropometric characteristics between moringa group and the control group have no significant difference. The average age of subjects is 17 years (control group) and 20 years in Moringa group. The height average of the two groups is $154 \mathrm{~cm}$ and the weight is $49 \mathrm{~kg}$.

\section{Parameters Measured in Research}

\section{The difference parameters average before and after the intervention.}

To see the average difference before and after treatment each group tested by pair sample t test as shown in Table 3 and Table 4 . In the Extract group (Table 3 ) showed significant differences in the increase in the value of hemoglobin $(p=0.001)$, ferritin $(p=0.012)$, MCHC $(p=0.003)$, RDW (0.013) and a decrease in platelets $(p=0.021)$. Significant increase in the control group parameters obtained in the hemoglobin value ( $\mathrm{p}=$ $0.004)$, erythrocytes $(\mathrm{p}=0.001)$, hematocrit $(\mathrm{p}=0.036)$ and $\mathrm{RDW}(\mathrm{p}=$ $0.00)$. While at MCV $(\mathrm{p}=0.037)$ and MCH $(\mathrm{p}=0.002)$ decreased significantly. The change in the value of other parameters is not significant ( $p>0.05$ ), probably due to inadequacy of the data to prove that there is a significant difference

During the supplementation period obtained an increase average in hemoglobin significant in both groups $(0.794 \pm 0.81 \mathrm{~g} / \mathrm{dl}, \mathrm{p}=0.001)$ for moringa group and the control group $(0.644 \pm 0.83 \mathrm{~g} / \mathrm{dl}, \mathrm{p}=0.004)$. In the literature described an increase in hemoglobin levels with consumption ferrous sulfate $300 \mathrm{mg}$ ( $60 \mathrm{mg}$ of iron) 1-2 times daily for 3-4 weeks will increase the hemoglobin $1-2 \mathrm{~g} / \mathrm{dl}^{3}{ }^{3}$ The mean increase in hemoglobin of non-pregnant women aged 15-49 years in developing countries is $0.864 \mathrm{~g} / \mathrm{dL}$, it is higher than that obtained by the researcher. However, when compared with studies of Idohou-Dossou et.al (2011) with an increase in the difference in mean hemoglobin $(0.40 \mathrm{~g} / \mathrm{dl})$ in the treatment group, the results obtained by researchers is higher.

The significant increase can be seen in ferritin serum levels in the moringa group of $29.378 \pm 42.48 \mathrm{ng} / \mathrm{ml}(\mathrm{p}=0.012)$. The results obtained are higher when compared to a research of Idohou-Dossou et al (2011) with no significant increase in $12 \pm 0.4 \mathrm{ng} / \mathrm{ml}(\mathrm{p}=0.601)$ in the group of moringa ${ }^{12}$. The results of ferritin obtained are lower when compared with 
spirulina research by Ramesh et al in 2013 showed a highly significant increase in the $58728 \pm 10170(\mathrm{p}=0.000)$.

Spirulina iron levels are 15-30 times than iron in moringa leaves and the duration of drug administration is a major factor in the blood ferritin serum improvement. According to the literature an increase in ferritin serum in 1-month consumption of 3-6 $\mathrm{mg}$ of $\mathrm{Fe} / \mathrm{kg}$ body weight per day or for 12 weeks of ferrous sulfate $300 \mathrm{mg}$ once daily consumption is more than $50 \mathrm{ng} / \mathrm{dL} .11 \mathrm{It}$ takes a minimum of 12 weeks in the treatment of iron deficiency anemia in order to fill the void of iron reserves in the bone marrow, liver and macrophages and pregnant women need a longer time during the 9 months of pregnancy and during lactation. ${ }^{12}$ For treatment with moringa leaves consumed to achieve optimal results for 3 months and preferably in the form of extracts because smaller than doses used.

Ferritin is an acute phase protein that increases its value to the state of inflammation and infection, so if at the time of taking the blood patients experiencing cough, colds or other infections it will increase the value of ferritin. Measurements of different acute phase proteins can help to interpret the value of ferritin serum if the concentration of the acute phase proteins is increased it indicates encountered inflammation. Checking acute-phase protein CRP that often used is (C-reactive protein) and a1acid glycoprotein (AGP), because it is increased quickly to the inflammation and also down quickly. The value may not reflect accurately the iron status in developing countries where malaria, HIV, seasonal infectious diseases, and tuberculosis are prevalent. ${ }^{2}$

The significant increase in erythrocyte can be seen in the control group with a mean difference of $0.475 \pm 0.52$ erythrocytes million $/ \mathrm{mL}$ ( $\mathrm{p}=$ 0.001 ), but not significantly in the moringa group with a mean difference of $0.482 \pm 2.26 \mathrm{million} / \mathrm{mL}(\mathrm{p}=0.394)$. When compared with the research of Gunadi, (2008) the difference in the mean increase in erythrocyte 0:24 \pm 0:57 million/uL ( $\mathrm{p}=0.03$ ) in the consumption of Fe three times a day. Gunadi Research (2008) was conducted in children aged 9-12 years with hemoglobin $<12 \mathrm{~g} / \mathrm{dl}$ was given a dose of $300 \mathrm{mg}$ three times daily $\mathrm{Fe}$ and $\mathrm{Fe}$ second group was given once daily for 4 weeks. ${ }^{13}$ It also should be considered the cause of secondary illnesses suffered by research subjects who have not been detected, diet and lifestyle subjects that cause the erythrocytes did not increase after administration of oral iron tablets regularly.

Hematocrit values were significantly increased in the control group with a mean difference $2.189 \pm 4.08 \%(\mathrm{p}=0.036)$ while in the moringa leaf were decreased $(4,558 \pm 0.95 \%)(p=0.404)$. According to research Idohou-Dossou et al in 2011, a significant hematocrit values also occurred in the control group with a mean of $1.6 \pm 2.55 \%(\mathrm{p}=0.002)$ and in the group of moringa leaf non-significant increase in hematocrit, $0.1 \pm 2.53 \%$ $(p=0.788) .{ }^{14}$ There is some significant increase in hematocrit in line with the increase in the number of erythrocytes in the blood and marks the start of an improvement of anemia, but the decline does not mean worsening anemia. There are several factors that affect them, the number of erythrocytes, if in the state of anemia; hematocrit will fall, thus helping the mechanisms of anemia faster. Some factors affecting hematocrit value besides a disease is malnutrition, deficiency of vitamin $\mathrm{B}$ and $\mathrm{C}$ (lower) and improve the condition of dehydration and hypovolemia. ${ }^{15}$

The results showed MCV decrease significantly in the control group with a mean difference value $(4,756 \pm 8.91 \mathrm{fL}) \mathrm{p}=0.036$. In the moringa group $(0.635 \pm 11.22 \mathrm{fL})(\mathrm{p}=0818)$. While research Idohou-Dossou et al in 2011, MCV values increased but not significantly. In the Moringa group $0.4 \pm 6.9 \mathrm{fL}$ and $\mathrm{p}=0.443$ and in control group $1.3 \pm 5.6 \mathrm{fL}, \mathrm{p}=0189 .{ }^{14}$ The decrease of MCV is influenced by the number of the erythrocyte. $\mathrm{MCV}$ is a parameter that sensitive toward changes in erythrocyte when compared with $\mathrm{MCH}$ and $\mathrm{MCHC}$ to determine the possibility of iron deficiency. The possibility of impairment of MCV strongly supports the iron deficiency anemia treatment that has not been completed so it takes extra time 2-3 weeks. The purpose is so that microcytic anemia can be corrected to achieve normal values.

Mean erythrocyte hemoglobin or $\mathrm{MCH}$ acquired shown a significant reduction in the control group $(2.183 \pm 2.47 \mathrm{pg}) \mathrm{p}=0.002$. This decrease is influenced by the value of the erythrocyte. While there is a significant increase in the moringa group $\mathrm{MCH}$ by $1.312 \pm 4,936 \mathrm{pg}, \mathrm{p}=0.028$. When compared with research of Idohou-Dossou, et al 2011, a significant increase seen in the moringa group and control group with consecutive values $(1.3 \pm 2.4) \mathrm{pg}, \mathrm{p}=0.001$ and $\left((1.7 \pm 2.05) \mathrm{pg}, \mathrm{p}=0.001 .^{14}\right.$

Mean erythrocyte hemoglobin levels or MCHC for Moringa group increased significantly with a mean difference of $2.459 \pm 2.86 \mathrm{~g} / \mathrm{dl}, \mathrm{p}=$ 0.003 , while in the control group were not significantly decrease $(0806 \pm$ $2.81 \mathrm{~g} / \mathrm{dl}$ ) and $\mathrm{p}=0.241$. It happened due to the influence of MCV and $\mathrm{MCH}$ values were also decreased. The results obtained showed a significant reduction in MCHC indicating ADB but not yet corrected.

RDW value of the results showed a significant improvement in both groups, respectively $1.4 \pm 2: 07 \%,(\mathrm{p}=0.013)$ for moringa group and $2,844 \pm 2.8 \%,(\mathrm{p}=0.000)$ for the control group. The increase of RDW indicates $\mathrm{ADB}$ has not reached normal values because it is necessary to increase the duration of therapy in order to return to normal RDW values along with increased MCV.

Based on the results of the statistical analysis there are no significant differences between the two groups, indicating moringa does not affect the increased production of leukocytes, although the contains of protein in moringa are quite high, about $27 \%$ of the nutrients of Moringa leaves. There is a non-significant decrease in moringa group in leukocytes and the control group actually increased, although non-significant. Leukocyte increased due to an external reaction in the bone marrow due to infection and inflammation, stress (spasms, anxiety) drugs. Leukocytes are physiologically affected by the physical activity of moderate-severe, emotional disturbances, seizures, paroxysmal tachycardia, and menstruation. Increased leukocytes can also be caused due to the occurrence of infection and acute inflammation, drugs, eg aspirin, procainamide, potassium iodide, sulfonamides, and others. ${ }^{16}$ Leukopenia can also be caused by drug use, especially acetaminophen, sulfonamides, PTU, barbiturates, diazepam, diuretics, indomethacin, methyldopa, and others. ${ }^{16}$ Platelet decline significantly in the group of moringa (-36529.41 \pm $59024.48 / \mathrm{uL})(\mathrm{p}=0.021)$ and control group $(18722.22 \pm 78553.6 / \mathrm{uL})$ $(\mathrm{p}=0.326)$. The decrease is due to lack of iron in the bone marrow that helps the production of platelets, antibiotic drugs (chloromycetin, streptomycin), sulfonamides, aspirin (salicylates) and others. In addition, it is also influenced by strenuous physical activity. ${ }^{16}$

\section{Comparison of the effectiveness of moringa group and control group}

To determine the statistical tests that will be used to process the data comparison of the effectiveness of moringa group and control group, the Independent test T-test has been done. There are significant differences in hematocrit, $\mathrm{MCH}, \mathrm{MCHC}$ and platelets (Table 5).

From the results of statistical analysis chi-square test was obtained factor that influence the body's iron status significantly with a p-value $(\mathrm{p}<0.05)$ was menstruating (affecting the value of ferritin, erythrocytes, and platelets) menstruating subjects in both groups. In the moringa group, the consumption of side dishes and fruit-vegetable affect hematocrit values. Whereas in the control group eating frequency affects the value of ferritin, the consumption of side dishes has a significant effect on the value of hemoglobin, ferritin, hematocrit and leukocyte and drinking affect the levels of ferritin.

Bioavailability and low iron levels in foods and types of foods typical of the population of Indonesia are known as one of the main causes of iron deficiency. ${ }^{17}$ In addition, the compliance of women of reproductive 
age to consume low iron supplements. In a study in lactating women in Senegal, only $88 \%$ of anemic women claimed to have consumed iron tablets but the number of tablets taken and the duration of treatment is unknown. ${ }^{14}$

Although the hemoglobin concentration increased significantly in Moringa and Moringa group ( $\mathrm{p}<0.05$ ) after the third week $64.7 \%$ of the sample in the Moringa group and $61.1 \%$ in the control group had a hemoglobin concentration of less than $12 \mathrm{~g} / \mathrm{dL}$. The possibility of the presence of intestinal parasites such as Schistosoma, Ankylosotomia, Ascaris lumbricoides and Trichuris trichloro affect the existence of iron with a comparison of several studies conducted in Indonesia showed the prevalence of $60-90 \% .^{18}$

Ferritin serum was also found to increase significantly in the moringa group and $54.7 \%$ of samples in the group of moringa have raised its iron reserves and $11.1 \%$ of samples in the control group. The increase of ferritin serum is in line with research Angeles-Agdeppa, et al 1997 in young Indonesian women who consumed iron supplements at a dose of $200 \mathrm{mg}$ of the element iron weekly for 3 months. ${ }^{2}$ In the control group no significant increase in ferritin serum and only $11.1 \%$ of the samples increased during the intervention. These results support the theory that the low bioavailability of iron in foods from plant sources. ${ }^{19}$

In another study on Moringa leaf, nutrient analysis and bioavailability of iron explain that the leaves contain protein and essential minerals but the iron levels that high enough in Moringa leaves have a low bioavailability $(2.2 \%)$. This is due to the polyphenol content which is a potent inhibitor of iron bioavailability. ${ }^{20}$

The inhibitory effect is related to the structure of the phenolic and catechol galloyl that form chelating complex polyphenols with iron and non-heme iron. ${ }^{19}$ So that the amount of iron consumed per day in the diet plus moringa leaf extract may be very low and not able to cover their daily needs. To improve the bioavailability of iron in the leaves of moringa according to Yang \& Tsou (2006) by cooking, boiling, heating so that the interaction with polyphenols reduced so the iron can be free. Fresh and dried leaf powder, when boiled, will increase the bioavailability of iron respectively 3.5 and 3 times. ${ }^{21}$

The effectiveness of moringa leaf water extract in Wistar rats at a dose of $400 \mathrm{mg} / \mathrm{kg}$, showed an increase in hematocrit hematologic parameters significantly, but the value of hemoglobin, erythrocytes, $\mathrm{MCV}, \mathrm{MCH}$ and MCHC showed no significant differences, and with higher doses actually reduce the value of hematological parameters of the mice. ${ }^{22}$ In contrast to research Madukwe, et al 2013 on the effectiveness of moringa leaf dry powder treat anemia in mice, results in a dose of $5 \%$ protein in moringa leaf powder seen a significant increase in hemoglobin values, PVC, and erythrocytes. But at a dose of $10 \%$ of the hematologic values decreased significantly. ${ }^{23}$

\section{Factors influencing changes in parameter values}

Coffee, milk, tofu, and noodles are statistically having no effect on the value of the parameter subjects (Table 6. This may be due to lack of data (number of samples) were processed to prove the effect of food on the parameters significantly. Meat and fish contain heme iron that well absorbed (20-30\%). The side dishes also increase the absorption of nonheme iron from foods consumed at the same time and dose dependent. Hallberg and Rossander (1984) found that the absorption of non-heme iron increased 2.5 -fold $(\mathrm{p}<0.01)$ after the addition of meat $(75 \mathrm{~g})$ into a food derived from corn, rice, and black beans. ${ }^{24}$

Mechanisms of animal protein increase the absorption of non-heme iron is a cysteine-containing peptide and the active components in the meat is of L-a-glycerophosphocholine, hydrolytic products of phosphatidylcholine (lecithin) which occurs in tissue. Phosphatidylcholine is one of the major phospholipids in cell (mostly in animals meat), consisting of glycerophosphocholine and branch chain hydrocarbons having acyl, alkyl or alkenyl and associated with phospholipid Phosphatidylcholine is also available as a natural phospholipid precursor and metabolite derived from soy lecithin, which can be used to increase the absorption of nonheme iron from vegetarian food. ${ }^{25}$

Polyphenols are found mainly in tea and coffee has the effect of reducing the absorption of non-heme iron and coffee which has about half the inhibitory effect of the inhibitory effect of tea. Other drinks such as red wine, cocoa, and teugae herb has proven to inhibit the absorption of non-heme iron. ${ }^{26}$ Black tea polyphenol is the most powerful potent inhibitor when compared green tea, cocoa or red wine, and there are reports that 20-50 mg of polyphenols reduce the amount of absorption of non-heme iron from white bread (50-70\%), while 100-400 mg polyphenols (equivalent to one cup of tea / instant coffee) reduce iron absorption of non-heme bread for $60-90 \%$ polyphenols Although the strong binding proteins, the addition of milk to black tea or coffee does not reduce the inhibitory effect of iron. ${ }^{24}$ Ascorbic acid has inhibitory effects against tannins and polyphenols on the absorption of non-heme iron which is about $50 \mathrm{mg}$ of ascorbic acid required to counteract the effects of $100 \mathrm{mg}$ of tannic acid. ${ }^{24}$

Calcium contained in foods or supplements have been reported to reduce the absorption of non-heme iron and heme iron. ${ }^{24}$ Calcium and iron compete for binding with one or more substances that are important in the absorption of Fe lines. The addition of calcium (40-600mg) on cereal grain significantly reduces the absorption of iron and inhibition occurred at a dose level of $300 \mathrm{mg}$. Greater inhibiting effect when calcium is added to the dough because it reduces the degradation of phytate during fermentation. Consumption of milk or cheese (equivalent to $165 \mathrm{mg}$ of calcium) to reduce the absorption of iron, respectively by $57 \%$ and $46 \% .^{24}$ Phytic acid (myoinositol hexaphosphate) is found in whole-grain cereals, nuts and seeds, soy protein (such as tofu and tempeh) have been proved to be inhibitors of iron absorption of non-heme ${ }^{10}$. The addition of $2 \mathrm{mg}$, $25 \mathrm{mg}$ and $250 \mathrm{mg}$ of phytate phosphorus (P-phytate) into bread significantly reduced iron absorption respectively $18 \%, 64 \%$ and $82 \%{ }^{26}$ The inhibitory effect of phytate on iron absorption may be reduced by vitamin $\mathrm{C}$ and an estimated $80 \mathrm{mg}$ of ascorbic acid required to counteract the inhibitory effect of $25 \mathrm{mg}$ P-phytate, and in very large doses are needed to overcome the inhibitory effect of high phytate diet (250 mg P -phytate).$^{26}$

The main mechanism of ascorbic acid increases the absorption of iron in the formation of the complex soluble iron that is easily absorbed and mechanisms that are able to reduce $\mathrm{Fe} 3$ to $\mathrm{Fe}^{2+}$. $\mathrm{Fe}^{2+}$ is a form of iron that can enter into mucosa cell. The effect of ascorbic acid against the iron inhibitory effect of the most effective absorption of foods is containing

Table 1: Summary results of the qualitative phytochemical screening of water extracts of Moringa leaves compared with other studies

\begin{tabular}{cccc}
\hline & & \multicolumn{2}{c}{ The other Research } \\
\cline { 3 - 4 } Secondary Metabolite Identification & Results & A & B \\
\hline Alkaloid & + & + & + \\
Anthraquinone & + & + & ND \\
Glycoside & + & - & + \\
Saponin & + & + & + \\
Phenol & + & + & + \\
Tannin & + & + & + \\
Flavonoid & + & + & + \\
\hline
\end{tabular}

Explanation: A) Nair, V.M, Roopalatha, U.C, (2013), B) Okwari, Emerole, Dasofunjo, Ezugwu, Obi, (2014).ND: Not Detected 
Table 2: Anthropometric characteristics of the study patients

\begin{tabular}{|c|c|c|c|c|}
\hline \multirow[b]{2}{*}{ Parameters } & \multicolumn{2}{|c|}{ Moringa } & \multicolumn{2}{|c|}{ Control } \\
\hline & Baseline & $\begin{array}{l}\text { Sig(2- } \\
\text { tailed) }\end{array}$ & Baseline & Sig(2-tailed) \\
\hline $\begin{array}{l}\text { Number of } \\
\text { samples }\end{array}$ & \multicolumn{2}{|c|}{$17(80.95 \%)$} & \multicolumn{2}{|c|}{$18(85.71 \%)$} \\
\hline Mild anemia & \multicolumn{2}{|c|}{$11(64.7 \%)$} & \multicolumn{2}{|c|}{$14(77.77 \%)$} \\
\hline $\begin{array}{l}\text { Moderate } \\
\text { anemia }\end{array}$ & \multicolumn{2}{|c|}{$6(35.3 \%)$} & \multicolumn{2}{|c|}{$4(22.17 \%)$} \\
\hline Age & $20.24 \pm 8.356$ & 0.003 & $17 \pm 1.572$ & 0.002 \\
\hline Weight & $50 \pm 4.301$ & $0.981^{*}$ & $48.33 \pm 2.88$ & $0.586^{*}$ \\
\hline Height & $155.12 \pm 4.78$ & $0.639^{\star}$ & $153.28 \pm 3.88$ & $0.924^{\star}$ \\
\hline $\begin{array}{l}\text { Body Mass } \\
\text { Index }\end{array}$ & $20.81 \pm 2.01$ & $0.328^{*}$ & $20.57 \pm 1.46$ & $0.835^{\star}$ \\
\hline
\end{tabular}

*) Normally distributed data if Sig. (2-tailed) / ( $>0.05)$, and showed no significant difference (homogeneous data)

Table 3: Mean difference parameters (before and after treatment) in the extract group

\begin{tabular}{ccccc}
\hline \multirow{2}{*}{ Parameters } & \multicolumn{4}{c}{ Moringa group } \\
\cline { 2 - 5 } & Baseline & $\begin{array}{c}\text { Post } \\
\text { Intervention }\end{array}$ & $\begin{array}{c}\text { Mean } \\
\text { Difference }\end{array}$ & $\begin{array}{c}\text { Sig(2- } \\
\text { tailed) }\end{array}$ \\
\hline Hemoglobin & $10.58 \pm 1.36$ & $11.37 \pm 1.46$ & $-0.794 \pm 0.81$ & $0.001^{*}$ \\
Ferritin & $11.90 \pm 22.14$ & $41.27 \pm 37.15$ & $-29.378 \pm 42.48$ & $0.012^{*}$ \\
Erythrocyte & $4.40 \pm 0.58$ & $4.70 \pm 1.39$ & $-0.482 \pm 2.26$ & 0.394 \\
Hematocrit & $33.64 \pm 3.90$ & $32.68 \pm 4.47$ & $0.947 \pm 4.56$ & 0.404 \\
MCV & $77.16 \pm 11.97$ & $76.52 \pm 12.63$ & $0.635 \pm 11.22$ & 0.818 \\
MCH & $24.62 \pm 4.84$ & $25.93 \pm 4.6$ & $-1.312 \pm 4.94$ & 0.289 \\
MCHC & $31.62 \pm 2.21$ & $34.08 \pm 2.31$ & $-2.459 \pm 2.86$ & $0.003^{*}$ \\
RDW & $15.18 \pm 3.12$ & $16.58 \pm 3.45$ & $-1.400 \pm 2.07$ & $0.013^{*}$ \\
\hline
\end{tabular}

*) Sig. (2-tailed) of $<0.05$, significantly different between before treatment (baseline) and after post-intervention
Table 4: Mean difference parameters (before and after therapy) in the control group

\begin{tabular}{ccccc}
\hline \multirow{2}{*}{ Parameters } & \multicolumn{4}{c}{ Control group } \\
\cline { 2 - 5 } & Baseline & $\begin{array}{c}\text { Post } \\
\text { Intervention }\end{array}$ & $\begin{array}{c}\text { Mean } \\
\text { Difference }\end{array}$ & $\begin{array}{c}\text { Sig(2- } \\
\text { tailed) }\end{array}$ \\
\cline { 2 - 5 } Hemoglobin & $10.93 \pm 1.02$ & $11.57 \pm 1.12$ & $-0.644 \pm 0.83$ & $0.004^{*}$ \\
Ferritin & $24.42 \pm 43.55$ & $47.82 \pm 65.07$ & $-23.407 \pm 58.60$ & 0.108 \\
Erythrocyte & $3.95 \pm 0.49$ & $4.43 \pm 0.48$ & $-0.475 \pm 0.523$ & $0.001^{*}$ \\
Hematocrit & $33.01 \pm 3.24$ & $35.19 \pm 3.36$ & $-2.189 \pm 4.08$ & $0.036^{*}$ \\
MCV & $83.03 \pm 11.69$ & $78.27 \pm 7.0$ & $4.756 \pm 8.91$ & $0.037^{\star}$ \\
MCH & $28.06 \pm 4.30$ & $25.87 \pm 2.6$ & $2.183 \pm 2.47$ & $0.002^{\star}$ \\
MCHC & $33.53 \pm 2.34$ & $32.72 \pm 1.59$ & $0.806 \pm 2.81$ & 0.241 \\
RDW & $13.36 \pm 2.12$ & $16.20 \pm 3.47$ & $-2.844 \pm 2.80$ & $0.000^{*}$ \\
\hline
\end{tabular}

*) Sig. (2-tailed) of $<0.05$, significantly different between before treatment (baseline) and after treatment (post-intervention)

Table 5: Comparison of the effectiveness of moringa leaves compared to the control

\begin{tabular}{cccc}
\hline \multirow{2}{*}{ Parameters } & \multicolumn{2}{c}{ Mean difference } & Sig.(2-tailed) \\
\cline { 2 - 4 } & Moringa group & Control group & $\begin{array}{c}\text { Equal variances } \\
\text { assumed }\end{array}$ \\
\hline Hemoglobin & $-0.794 \pm 0.81$ & $-0.644 \pm 0.83$ & 0.594 \\
Ferritin & $-29.378 \pm 42.48$ & $-23.407 \pm 58.60$ & 0.734 \\
Erythrocyte & $-0.482 \pm 2.26$ & $-0.475 \pm 0.523$ & 0.066 \\
Hematocrit & $0.947 \pm 4.56$ & $-2.189 \pm 4.08$ & $0.039^{*}$ \\
MCV & $0.635 \pm 11.22$ & $4.756 \pm 8.91$ & 0.212 \\
MCH & $-1.312 \pm 4.94$ & $2.183 \pm 2.47$ & $0.012^{*}$ \\
MCHC & $-2.459 \pm 2.86$ & $0.806 \pm 2.81$ & $0.002^{*}$ \\
RDW & $-1.400 \pm 2.07$ & $-2.844 \pm 2.80$ & 0.093 \\
\hline
\end{tabular}

*) Sig. (2-tailed) of $<0.05$, significantly different between the Moringa group and control group

Table 6: Assessment of factors affecting the intake of iron status through changes in parameter values

\begin{tabular}{cccccccccccccccccc}
\hline Parameters & M ens & \multicolumn{1}{c}{ Animal Protein } & \multicolumn{2}{c}{ Tea } & \multicolumn{2}{c}{ Coffee } & \multicolumn{3}{c}{ Milk } & \multicolumn{2}{c}{ Fruits-Vegetables } & Tofu-temp eh & Noodles \\
\hline & truation & A & B & A & B & A & B & A & B & A & B & A & B & A & B \\
\hline Hemoglobin & 1.00 & 0.08 & $0.01^{*}$ & 0.10 & 0.33 & 1.00 & 0.53 & 0.54 & 1.00 & 0.25 & 1.00 & 0.43 & 0.53 & 1.00 & 1.00 \\
Ferritin & $0.01^{*}$ & 1.00 & $0.05^{*}$ & 1.00 & $0.00^{*}$ & 1.00 & 1.00 & 1.00 & 0.29 & 0.41 & 1.00 & 1.00 & 0.21 & 1.00 & 0.58 \\
Erythrocyte & $0.04^{*}$ & 0.06 & 0.25 & 1.00 & 1.00 & 0.08 & 0.44 & 0.58 & 0.17 & 0.33 & 1.00 & 0.47 & 1.00 & 1.00 & 1.00 \\
Hematocrit & 0.23 & $0.00^{*}$ & $0.04^{*}$ & 0.15 & 0.62 & 0.58 & 1.00 & 1.00 & 1.00 & $0.05^{*}$ & 1.00 & 0.47 & 0.25 & 0.62 & 1.00 \\
MCV & 0.63 & 0.35 & 0.33 & 0.64 & 1.00 & 0.29 & 1.00 & 021 & 0.25 & 0.64 & 0.27 & 0.47 & 0.52 & 0.13 & 0.53 \\
MCH & 0.11 & 0.34 & 0.33 & 1.00 & 1.00 & 0.24 & 1.00 & 0.51 & 1.00 & 0.30 & 0.27 & 0.51 & 0.52 & 0.60 & 1.00 \\
MCHC & 0.25 & 0.29 & 1.00 & 1.00 & 0.60 & 0.52 & 1.00 & 0.54 & 0.29 & 1.00 & 0.13 & 1.00 & 0.21 & 0.54 & 1.00 \\
RDW & 0.23 & 0.13 & 1.00 & 0.64 & 1.00 & 0.09 & 1.00 & 1.00 & 1.00 & 0.64 & 1.00 & 0.11 & 1.00 & 1.00 & 1.00 \\
Leukocyte & 0.69 & 0.64 & $0.01^{*}$ & 1.00 & 1.00 & 0.29 & 0.53 & 1.00 & 0.33 & 0.64 & 0.63 & 021 & 0.53 & 0.13 & 1.00 \\
Platelets & $0.02^{*}$ & 0.62 & 1.00 & 0.60 & 1.00 & 1.00 & 1.00 & 0.19 & 0.61 & 1.00 & 1.00 & 1.00 & 1.00 & 0.60 & 0.47 \\
ESE. & 0.69 & 0.33 & 0.63 & 1.00 & 0.62 & 0.24 & 1.00 & 1.00 & 1.00 & 1.00 & 0.34 & 0.51 & 0.51 & 1.00 & 1.00 \\
\hline
\end{tabular}

$(\mathrm{p}<0.05)$, different significant, $\mathrm{A}=$ Moringa Group, $\mathrm{B}=$ Control Group 
high phytate and polyphenols. ${ }^{26}$ The effect of ascorbic acid towards meat in facilitating the absorption of non-heme iron, showed the addition of ascorbic acid $(100 \mathrm{~g})$ for foods containing beef and the result of absorption increased 4 -fold compared with the food without beef is only 1.67 fold increase iron.

A slight improvement in the hemoglobin concentration on moringa group can be explained by an increase in protein intake or in the presence of ascorbic acid and beta-carotene in the leaves of moringa powder, which is a non-heme iron enhancers. The content of protein (amino acids) can also contribute to the activity of erythropoietin by providing amino acids for porphyrin, globin and transferrin synthesis. ${ }^{27}$

\section{CONCLUSION}

Based on the analysis of the results of this study concluded that supplementation of Moringa leaf water extract as a natural supplement in addition to ferrous sulfate can help overcome iron deficiency anemia. Extract of moringa leaves as an add-on therapy showed improvement in mean hematocrit values, $\mathrm{MCH}, \mathrm{MCHC}$ and platelet decrease and mean difference in the parameter values of Moringa group significantly on the value of hemoglobin, ferritin serum, MCHC, RDW, and platelets. However, in the control group also found an increase in hemoglobin, erythrocyte, hematocrit, MCV, MCH and RDW post-treatment compared before. Factors that affect the value of such parameters are menstruation (effect on the value of ferritin, erythrocytes, and platelets) in both groups. In moringa group, foods which affect the parameters are sided dishes and fruit-vegetable that affects hematocrit values, whereas, in the control group, the side dishes affect the value of hemoglobin, ferritin, hematocrit and leukocyte and tea consumption on ferritin serum values.

\section{ACKNOWLEDGEMENT}

This study financially was supported by Directorate of Higher Education, Ministry of National Education through Hibah PUPT 2014.

\section{CONFLICT OF INTEREST}

None.

\section{ABBREVIATIONS USED}

MCH: Mean corpuscular hemoglobin; MCHC: Mean corpuscluar hemoglobin concentration; MCV: Mean corpuscular volume; RDW: Red distribution wide.

\section{REFERENCES}

1. McLean E, Cogswell ME, Egli I, Wojdyla D, de Benoist B, Mary B. Worldwide prevalence of anemia, World Health Organization vitamin and mineral nutrition information system 1993-2005. Public Health Nutrit, 2009;12:444-54. https:// doi.org/10.1017/S1368980008002401; PMid:18498676.

2. World Health Organization. Iron deficiency anemia: Assessment, prevention, and control. A Guide for Programme Managers of WHO, Geneva; 2001.

3. Cogswell ME, Parvanta I, Ickes L, Yip R, Brittenham GM. Iron supplementation during pregnancy, anemia, and birthweight: a Randomized controlled trial. American J Clin Nutrit, 2003;78(4):773-81. PMid:14522736.

4. Pavord S, Myers B, Robinson S, Allard S, Strong J, Oppenheimer C. UK guidelines on the management of iron deficiency in pregnancy. British Committee for Standards in Haematology. London, 2011;1-34.

5. Ministry of Health of the Republic of Indonesia. Anemia gizi dan tablet tambah darah (TTD), untuk wanita usia subur (WUS). Jakarta: Direktorat Gizi Masyarakat, Direktorat Jenderal Bina Kesehatan Masyarakat. 2005.
6. Fahey JW. Moringa oleifera: A review of the Medical and Plant for Its nutritional, Therapeutic, and Prophylactic Properties. Part 1. In: trees for Live of Journal. Beneficial Trees and Plants. Maryland. 2005;1(5):1-5.

7. Mun'im A, Puteri MU, Sari SP, Azizahwati. Anti-anemia effect of standardized extract of Moringa oleifera Lamk. leaves on aniline induced rats. Pharmacogn J 2016;8(3);255-8. https://doi.org/10.5530/pj.2016.3.14

8. Fuglie, Lowell J, et al.The Miracle Tree: Moringa Olifura: Natural Nutrition forThe Tropics. Training Manual. Church World Service, Dakar, Senegal; 2001

9. Oomen, HAPC. \& GJH. Grubben. Tropical Leaf Vegetables in Human Nutrition Communication 69, Department of Agriculture Research, Royal Tropical Institute, Amsterdam;1978. PMid:623967

10. Milasius R, Malickaite R \& Dadeliene. Effect of spirulina food supplement on blood morphological parameters, biochemical composition and on the immune function of Sportsmen. Biol Sport J, 2009;26:744-9. https://doi. org/10.5604/20831862.890162.

11. Brittenham GM, Hoffman R, Benz EJ, Jr. Silberstein LE, Heslop HE, \& Weitz JI. Disorders of Iron Homeostasis: Iron Deficiency and Overload. Hematology: Basic Principles and Practice. Philadelphia. 2012;6(4):544-51.

12. Koss W, Koepke JA, Martin EA, \& Steininger CA. Anemias of abnormal iron metabolism and hemochromatosis. Clin Haematol, Prin Proced Correl, Lippincott Philadelphia. 1998;9:979-1010.

13. Gunadi D . Perbandingan Respon terapi besi satu kali dan tiga kali sehari pada anak sekolah dasar usia 9-12 tahun yang menderita anemia defisiensi besi. Thesis Universitas Sumatera Utara, Indonesia (2008).

14. Idohou-Dossou N, Diouf A, Gueye AL, Guiro AT \& Wade S. Impact of daily consumption of Moringa oleífera dry leaf powder on iron status of Senegalese lactating women. African J Food Agric Nutrit Develop. 2011;11(4):4985-99. https:// doi.org/10.4314/ajfand.v11i4.69176.

15. Ministry of Health of the Republic of Indonesia. Pedoman interpretasi data klinik. Jakarta: Direktorat Pelayanan Kefarmasian, 2011.

16. Vajpayee N, Graham SS \& Bem S. Basic examination of blood and bone marrow. In: Henry's Clinical Diagnosis and Management by Laboratory Methods. (21sted). Editor: McPherson RA, Pincus MR. China: Saunders Elsevier. 2006;7:9-20.

17. Hayati, M. Pengetahuan dan sikap anemia defisiensi besi dan dampaknya terhadap kesehatan reproduksi di MAL IAIN Medan tahun 2009/2010.Thesis Magister, Program Pascasarjana Universitas Sumatera Utara, Medan, 2010.

18. Sihotang, SD \& Febriyani N. Pengetahuandan sikap remaja putri tentang anemia defisiensi besi di SMA Negeri 15 Medan. Thesis.Program Pascasarjana Universitas Sumatera Utara, Medan. (2012).

19. Sandberg A.S. Bioavailability of minerals in legumes. Brit J Nutrit, 2002;88(S3):281-5. https://doi.org/10.1079/BJN/2002718; PMid:12498628

20. Ndong M, Guiro AT, Gning RD, Idohou-Dossou1 N, Cissé1 D \& Wade S. In vitro iron bioavailability and protein digestibility of traditional Senegalese meals enriched with Moringa oleifera leaves powder. African J Food Agric Nutrit Devel, 2007:7:1-17.

21. Yang RY \& Tsou SCS. Enhancing iron bioavailability of vegetables through proper preparation-principles and applications. J Inter Coop, 2006;1(1):107-19.

22. Adedapo AA, Mogbojuri OM \& Emikpe BO. Safety evaluations of the aqueous extract of the leaves of Moringa oleifera in rats. J Med Plants Res, 2009;3(8):586-91

23. Madukwe EU, Ezeugwu JO \& Eme PE. Nutrient composition and sensory evaluation of dry Moringa oleifera aqueous extract. Inter J Basic Appl Scie, 2013;13(03):100.

24. Hallberg $L$ \& Rossander L. Improvement of iron nutrition in developing countries: Comparison of adding meat, soy protein, ascorbic acid, citric acid, and ferrous sulfate on iron absorption from a simple latin American-Type of meal. American J Clin Nutrit, 1984;39(4):577-83. PMid:6538742.

25. Teucher $B$, Olivares $M$ \& Cori $H$.Enhancers of iron absorption: Ascorbic acid and other organic acids. Inte J Vitamin Nutr Res, 2004;74(6):403-19. https://doi. org/10.1024/0300-9831.74.6.403; PMid:15743017.

26. Hallberg L. Wheat Fiber, Phytates and Iron Absorption.Scand J Gastroenterol, 1989;129:73-9.

27. Koury MJ \& Ponka P. New insights into erythropoiesis: the Roles of folate, vitamin B12, and iron. Annual Rev Nutrit, 2004;24:105-31. https://doi.org/10.1146/ annurev.nutr.24.012003.132306 ; PMid:15189115. 